\title{
Pridolian graptolites and their use in correlation
}

\author{
LECH TELLER
}

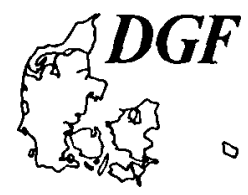

Teller, L.: Pridolian graptolites and their use in correlation. Bull. geol. Soc. Denmark vol. 35, pp. 217-222, Copenhagen, July 1st, 1987. https://doi.org/10.37570/bgsd-1986-35-23

\begin{abstract}
The use of graptolites to subdivide the youngest (Pridoli) stratotype of the Silurian System in the Barrandian poses difficulties for correlation with other regions. The proposed zonal subdivision is the same as that established earlier by Pribyl in 1940. Since that time, however, various graptolites of the same age have been recognized in several sections all over the world. This abundance of new data makes detailed zonal correlation with the Barrandian area much more difficult because the Barrandian graptolites are probably not fully documented. The absence of some taxa may be due to condensed carbonate sedimentation in which sedimentary gaps are to be expected. It can not be excluded, however, that undiscovered graptolites still exist in the Pridoli Series of the type area.

The graptolites aside, other faunal groups in the Pridoli Series are unfortunately strongly endemic and thus their correlation value is weak.
\end{abstract}

L. Teller, Department of Palaeobiology of the Polish Academy of Sciences, Unit for Graptolite Research, Newelska 6, Pl. 01-447 Warszawa, Poland. November 4th, 1985.

The youngest Silurian Series, the Pridoli, was created in 1984 and has its stratotype in the Barrandian (the Pozary section) a few kilometres SW of Prag. The detailed characteristics of the Series and its stratotype section have been elaborated by a team of authors in two complementary submissions to the IUGS Subcommission on Silurian Stratigraphy (Jaeger, Križ \& Schönlaub 1981; Križ et al. 1983). The Subcommission's final decision followed discussions based upon these two submissions. In fact, the Subcommission did not visit the chosen Barrandian stratotype, in contrast to the procedure adopted when choosing the Llandovery, Wenlock and Ludlow Series stratotypes, and when even though other potential candidates were examined i.a. Anticosti, Podolia, Downton area, Oslo Region. This departure from accepted practice was, in the present author's opinion, unjustified, particularly as the Barrandian area is easily accessible. The procedures adopted are now immaterial since the Subcommission has formaly chosen the Pridoli Series stratotype, but the implications of this decision need further consideration.

According to Hedberg (1976), a stratotype section should fulfill certain criteria including not only (and most important) continuity of sedimentation and lack of tectonic disturbances but also the possibility of proper faunal correlation with other time equivalent sections elsewhere.
Graptolites are the only group useful for precise correlation found at the Pozary section. Consequently correlation of the entire Pridoli Series relies on graptolites. Also graptolites have been employed to define the boundary between the Ludlow and Pridoli Series. In the light of data from other equivalent sections doubts about the validity of this boundary makes correlation more difficult.

\section{Graptolite zonal sequences of the Pridoli Series}

A standard zonation of the Pridoli was proposed by Jaeger (in Jaeger et al. 1981). He differentiated seven graptolite zones, with the base of the oldest zone defining the Ludlow/Pridoli boundary (fig. 1). This subdivision is only a slight modification of the scheme established by Pribyl (1940). A somewhat modified graptolite zonation of the Pridoli Series in the Barrandian and its correlation with other regions was given by Pribyl (1983). In contrast to Jaeger, Pribyl equated the base of the Pridoli with the appearance of $M$. ultimus. Přibyl (1941) had already established the $M$. pridoliensis ( $=M$. similis) Zone above the $M$. ultimus Zone, but the succeeding zonation was identical with his original 1940 scheme.

Both Jaeger (in Jaeger et al. 1981) and Přibyl 
Fig. 1. Upper Ludlow and Pridoli Graptolite Biozones correlation in the selected main sections.

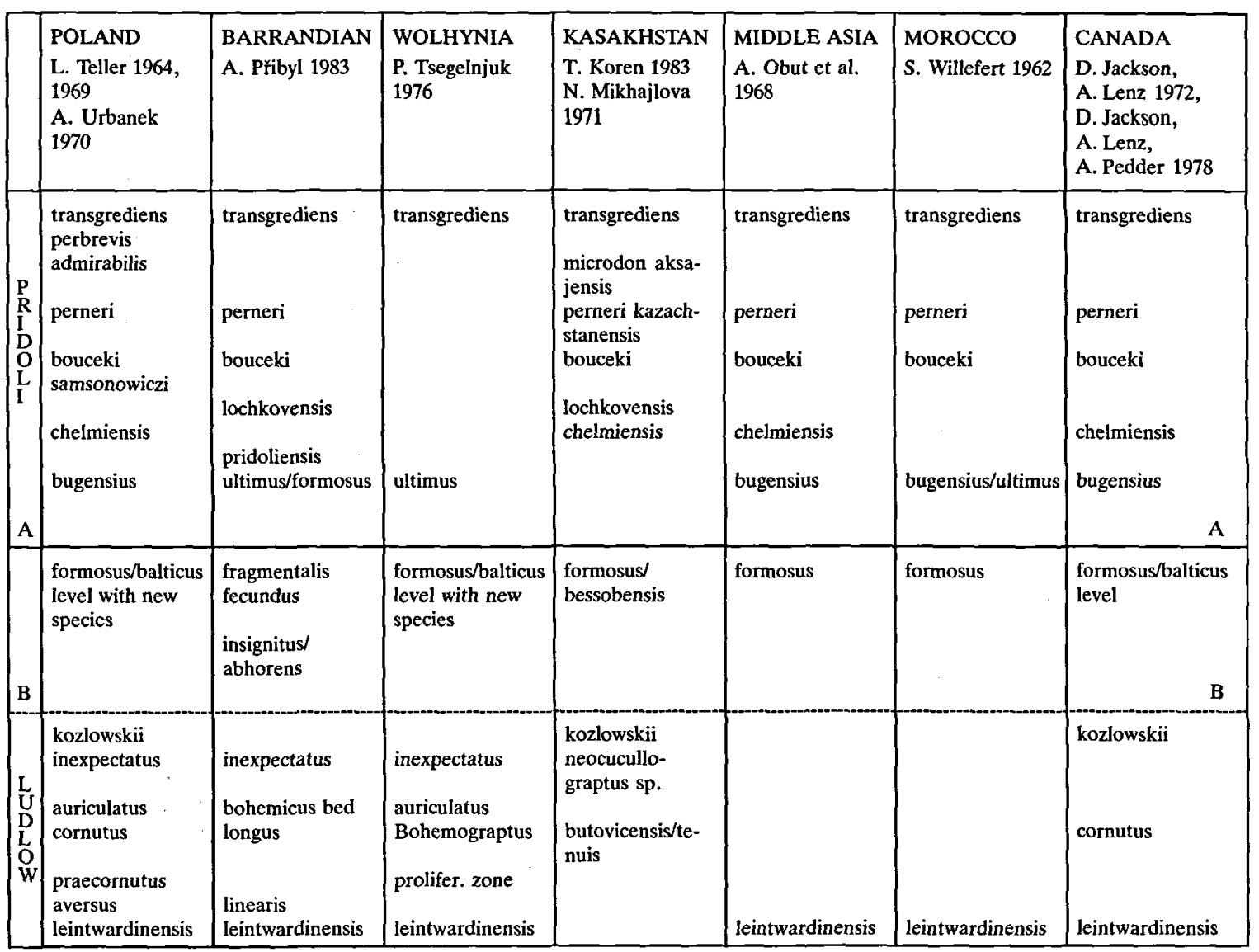

A-A - present Ludlow/Pridoli boundary

B-D - proposed boundary.

$(1940,1981,1983)$ mentioned only a few species which occurred together with the index form, indicating a great impoverishment of the graptolite fauna during this interval. In the $M$. ultimus or $M$. parultimus biozones, both $M$. kolednikensis and (very important) $M$. formosus always occur together with index forms. Linograptus posthumus and dendroid graptolites occur in all other zones of the Pridoli Series. $M$. rectiformis appears above the $M$. pridoliensis Zone, some 10-18 metres over the base of the Series.

\section{Graptolites of the Pridoli Series in sections outside the Barrandian}

It is more than 45 years since Pridoli graptolites were recognized in the Barrandian. Since that time our world-wide knowledge of Ludlow, Pridoli and Lower Devonian graptolite faunas has advanced markedly. Pridoli graptolites have been recognized in Poland (Teller 1964, 1969), Lithuania (Paškevicius 1979), Wolhynia (Tsegelnjuk 1976), the Carnic Alps (Jaeger 1976), Morocco (Willefert 1962), Kazakhstan (Mikhajlova 1971, 1975, 1976; Koren 1983), Kirgizia (Koren, pers. comm.), southeastern Australia (Jenkins 1982), northern Yukon, Canada (Jackson \& Lenz 1972, 1978; Lenz 1966), Cornwallis and Little Cornwallis Islands (Thorsteinsson 1958), Nevada, USA (Berry \& Murphy 1975), and other smaller outcrops (fig. 1).

Only fragments of the complete Pridoli graptolite zonal scheme are represented at most of these localities, so those sections which are fully developed and contain a rich and diverse grapto- 
lite fauna deserve special attention. Such a section was described by Tomczyk \& Teller (1956) from the Chelm borehole, east Poland. At that time, it was only the second unbroken Pridoli graptolite sequence known.

Another important Pridoli section has been described more recently. It is that of the Tokrau horizon in Kazakhstan, which is assigned to the Pridoli on the basis of a graptolite fauna partially documented by Mikhajlova $(1971,1975,1976)$ and subsequently more comprehensively illustrated and described by Koren (1983). An important new section was discovered recently by Koren (pers. comm.) in Kirgizja, Middle Asia. Among the little recognized regions of the world where the Pridoli Series contain a very rich graptolite fauna is the northern Yukon (Jackson \& Lenz 1972, 1978, Jackson, Lenz \& Pedder 1978, Lenz \& Jackson 1971).

It is remarkable that in all of the above sections the documented graptolites are both more abundant and more diverse than in the Barrandian. Accordingly such profiles are more easily correlated with each other than directly with the stratotype.

Other sections in which graptolites of Pridoli age have been documented are, as a rule, representative of only part of the Pridoli. They yield only some zonal index forms: e.g. Thuringia, eastern Serbia, Sardinia, the Carnic Alps, Morocco, Lithuania, Latvia, Nevada and Australia. These sections usually contain members of the formosus s.l. group, which occurs, as a rule, in the lower Pridoli, either alone or with $M . u l$ timus.

$M$. bouceki and $M$. perneri occur in the Middle Pridoli, while the upper part contains $M$. transgrediens. All these forms have been described from the Barrandian and permit a more or less precise correlation with that area; their presence is sufficient to confirm the bouceki, perneri and transgrediens Zones, but correlation of the lower parts of the sections remains controversial.

\section{The lower boundary of the Pridoli Series}

Bed 96 of the Pozary stratotype section contains the lower boundary of the Pridoli Series at the first appearance of the index species $M$. parul- timus. This also, by definition, marks the top of the Ludlow Series, which according to Pribyl (1983), also defines the top of the $P$. fragmentalis Zone. $M$. ultimus also occurs in an equivalent position in the Cephalopod and Kossov Quarries and at Branik. M. parultimus occurs together with $M$. formosus in the Marble and Kolednik Quarries, while at the Muslovka and Hvizdzalka Quarries the latter is absent. According to Jaeger et al. (1981) true $M$. ultimus occurs above $M$. parultimus both in the stratotype section, in the Marble and Cephalopod Quarries, and at Branik.

Prribyl considers (pers. comm.) the erection of $M$. parultimus unjustified and, accordingly, that the base of the Pridoli in the Barrandian is marked by the appearance of $M$. ultimus. The stratigraphic position of $M$. parultimus in the Barrandian, even accepting that its creation is justified, is equivocal. This throws some doubt on the correctness of the established lower boundary of the Pridoli Series.

Accepting Pribyl's view, it should be emphasized that in the Barrandian M. ultimus s.l., always occurs together with $M$. formosus s.l. and that in the type locality of $M$. formosus, both species are restricted to a very thin band. This is direct opposite to the situation in Poland, Wolhynia and Canada where the $M$. formosus s.l. and $M$. ultimus s.l. groups are not only strongly differentiated but also occur in older horizons and have long vertical ranges.

Differences in the vertical distribution of $M$. ultimus and $M$. formosus, the impoverishment of the graptolite fauna in general, the lack of several phylogenetic lines in the Barrandian when compared with other sections, and the consequent inaccuracy in the determination of the lower boundary of the Pridoli Series, all arise, in the present author's opinion, from the tectonic and palaeogeographic position of the Barrandian and from the specific character of its sedimentary environment.

Lithologically, the Pridoli Series in the Barrandian is characterized by the predominance of carbonates over intercalated clays. Analyses of the circumstances of deposition reveal the presence of breaks or out washings (hard grounds) and sharp sedimentary and erosional boundaries, as well as significant lithological changes. Commonly volcanic activity can also be traced, being 
marked by the presence of tuffs and diabases. These features argue against continuous deposition and are factors important for the occurrences of the graptolites. It seems that the graptolite plankton reached the Barrandian area of carbonate-clay deposition rather sporadically, hence the meagreness of the fauna when compared with other regions where thick clayey deposits predominate in mio- or eugeosynclines. This episodic appearance of graptolites in the Barrandian allows to presume the lack of continuity of several phylogenetic lines. This is not only limited to the Pridoli Series, but it can be traced also in the Ludlow Series, especially from the top of $N$. inexpectatus Zone upward (fig. 1).

\section{Character of the graptolite fauna at the Ludlow/Pridoli boundary}

The Upper Ludlow saw the disappearance of nearly all previously dominant lineages:neocucullograptine evolution terminated with $N$. kozlowskii; most Ludlow Monograptidae disappeared with only the linograptids and some $M$. dubius s.l. forms surviving.

The subsequent, still inadequately known, development of several new phylogenetic lines of Monograptidae is characterized by the appearance of forms with strongly differentiated uniand biform thecae, showing great morphological homology. All the forms are very difficult to determine when not isolated from the rock.

Urbanek (1971) recognized the presence of a post $N$. kozlowskii Zone fauna in the Upper Silurian and Teller (1966) already had described two new species, $M$. balticus and $M$. lebanensis from that level. Tsegelnjuk's (1976) comprehensive paper on the graptolite fauna from this interval was based on material from the Wolhynia borehole. He created several new genera and species, but not all of these unfortunately can be accepted. A closely similar graptolite fauna, most probably of the same age, was described by Mikhajlova (1975) and Koren (1983) from the Tokrau horizon in Kazakhstan. Another very abundant, contemporaneous fauna (again not fully worked out) has been documented by Koren (pers. comm.) from Kirgizja.

Beside these complete sections with the continuity of several morphotypes of $M$. ultimus s.l.,
M. formosus s.l., $M$. balticus s.l., $M$. bouceki s.l., $M$. latilobus s.1., $M$. perneri s.1., $M$. insignitus s.l., $M$. abhorens s.l., $M$. nimius s.l., $M$. supinus s.l. and others, sections with single representatives of these groups are known (e.g.: Lithuania, the Carnic Alps, Morocco, Australia, Canada, Nevada).

In the present author's opinion, the time interval represented by the above listed assemblage embraces the Ludlow/Pridoli boundary in the Barrandian. The boundary status would be in no doubt if it were not for the fact that in the Barrandian area, only representatives of the $M$. formosus s.l., $M$. insignitus s.1., $M$. abhorens s.l., $M$. ultimus s.l. and less characteristic $P$. fecundus, $P$. fragmentalis, and $P$. longus are found. Other forms are missing or not known up to day. Consequently, the designated boundary is not defined precisely enough to allow definite correlation with other regions.

The graptolite fauna of the Pridoli Series as presently understood clearly differs from that of both the older Ludlow and younger Lower Devonian. The graptolite fauna consists of several phylogenetic lines restricted to the Pridoli itself. The forms are predominantly biform with clearly differentiated apertures at the proximal end of the colony. There are several morphotypes present: $M$. lochkovensis, $M$. chelmiensis, $M$. samsonowiczi, $M$. admirabilis, $M$. separabilis, $M$. perbrevis and $M$. transgrediens. The latter is the youngest representative of the Silurian and disappears slightly below the Silurian/Devonian boundary. A new phyletic sequence already connected with the Lower Devonian started with the $M$. angustidens $-M$. uniformis line.

The Pridoli assemblage is characterized by a clear impoverishment of species over that of the Ludlow and their weak morphologic differentiation makes identification very difficult.

All the above factors affect the precise designation of the base of the Pridoli Series in the Barrandian. It must be stressed that to place it at the bottom of the $M$. ultimus or parultimus Zones is misleading. Such boundary is not a natural one because it cuts both the $M$. ultimus s.1. and $M$. formosus s.l. group lineages at a currently unknown level. Only a detailed investigation of both lineages (and others in the new graptolite fauna) will settle this problem.

The question also arises whether the Ludlow/ 
Pridoli boundary should be based on the development of the $M$. ultimus s.l. group or whether other natural premises exist for its designation. It should be noted that between the top of the $N$. kozlowskii Zone and the base of the presently accepted $M$. parultimus Zone a very rich and well differentiated assemblage exists. It is also significant that the last representatives of that evolutionary sequence are most probably $M$. bouceki and $M$. perneri - both already accepted as being Pridoli of age.

The new evolutionary sequence started with the appearance of the $M$. formosus s.l. and $M$. balticus s.l. morphotypes, an event that is not only well marked in the vertical profile but also represents a precise natural boundary. Such an event should, in the present author's opinion, define the Ludlow/Pridoli boundary.

\section{Value to correlation of the Pridolian non-graptolite fauna in the Barrandian}

The Pridoli Series in the Barrandian is distinquished by the presence of very diverse and rich non-graptolite fauna. It is, however, very endemic in character. Accordingly its value for correlation is limited. This affects especially any attempt to correlate with regions of the Caledonian geosyncline where graptolite clay predominate, and with their epicontinental shelf sea surroundings where carbonate-marly facies are dominant. The Barrandian area can be correlated easily with the Mediterranian regions of the Prothetis where approximately similar facies and fauna occur.

One of the most important non-graptolite groups for correlation is the conodonts (Schönlaub, in Križ et al. 1983). A detailed analysis of their vertical distribution shows, however, that a precise stratigraphy of the Pridoli Series is very limited. The single typical, and unfortunately longlived species, Ozarkodina eosteinhornensis, had already made its appearance in the Ludlow. It survived through most of the Pridoli. Moreover the conodont fauna was better worked out for the Ludlow than for the Pridoli in 1964 by Walliser.

Great stratigraphical significance has also been assigned to the chitinozoa by Paris (in Križ et al. 1983) based on two biozone assemblages and a few single species. The first assemblage-Eise- nackitina sp.n. 1, is not precisely Pridolian because some of its component species overlap the presently accepted Ludlow/Pridoli boundary. The second assemblage is characterized by the presence of Urochitina gr. urna, which appears at the base of the Pridoli; the vertical range of its component species is limited to the Pridoli. Its important members include Pterochitina perinelata, Linochitina klonkensis and Fungochitina sp.n. 1. The Urnochitina gr. urna assemblage was considered cosmopolitan by Paris (in Križ et al. 1983).

Other fossil groups have been briefly described by several authors (e.g. Križ et al. 1983), but of no help to further clarify the biostratigraphy and correlation of the Pridoli Series.

\section{Conclusions}

1. The established Barrandian stratotype of the Pridoli Series at Pozary is characterized by a specific type of depositional environment within which the existence of sedimentary gaps cannot be excluded. Consequently the record of graptolite phylogenetic lineages is likely to be discontinuous.

2. The graptolite fauna, which defines the standard zonal subdivision is not sufficiently well known in the Barrandian; problems occur when attempts are made to correlate Pridoli graptolites with more diverse and abundant assemblages in regions where different facies predominate.

3. Doubt is cast upon the correctness of the established lower boundary of the Pridoli Series by its cutting artificially, at an unknown point, the $M$. ultimus s.l. and $M$. formosus s.l. group lineages.

4. The morphologically highly differentiated graptolite assemblage which occur above the $N$. kozlowskii Zone in several sections across the world is absent from the Barrandian.

5. The established Ludlow/Pridoli boundary should be relocated at the point where representatives of the balticus/formosus groups first appear, or at the top of the N. kozlowskii Zone. Such a boundary will separate two naturally different evolutionary sequences and in this way will be analogous to the Landovery/ Wenlock, Wenlock/Ludlow and Silurian/Devonian boundaries. 
6. The non-graptolite Barrandian fauna of the Pridoli Series is very endemic in character and cannot be used for correlation in any useful way.

Acknowledgements. The author wishes to thank Dr. Peter Crowther from the Leicestershire Museums Service for improving the English of the manuscript.

\section{Dansk sammendrag}

Anvendelsen af graptolitfossiler til at underopdele den yngste del af siluret (Pridoli stratotypen) indenfor Barrandian skaber problemer med hensyn til korrelation med andre regioner. Den foreslåede zonering er identisk med den, der blev foreslået af Pribyl i 1940. Efter dette tidspunkt er forskellige graptolitter af samme alder blevet fundet forskellige steder $\mathrm{i}$ verden. Fremkomsten af alle de nye fund gør en korrelation med Barrande området mere vanskeligt, fordi Barrande-områdets graptolitter nok ikke er tilstrækkeligt veldokumenterede. Fravaret af visse arter kan skyldes kondenserede carbonat sekvenser i hvilke huller i lagrækken kan forventes. Det kan imidlertid ikke udelukkes, at der eksisterer endnu upåviste graptolitter i Pridoli Serien.

Når man ser bort fra graptolitterne, er de andre faunagrupper stærkt endemiske og derfor af ringe korrelationsværdi.

\section{References}

Berry, W. B. N. \& Murphy, M. A. 1975: Silurian and Devonian graptolites of Central Nevada. University of California Publication in Geological Sciences 110. pp. 1-109.

Hedberg, H. D. 1976: International stratigraphic guide. J. Wiley \& Sons. New York. pp. 1-189.

Jackson, D. E. \& Lenz, A. C. 1972: Monograptids from the Upper Silurian and Lower Devonian of Yukon Territory, Canada. Palaeontology 15. pp. 579-597.

Jackson, D. E., Lenz, A. C. \& Pedder, A. E. H. 1978: Late Silurian and Early Devonian Graptolite, Brachiopod and Coral faunas from Northwestern and Arctic Canada. Geological Association of Canada, Special Paper 17. pp. 1159.

Jaeger, H. 1976: Das Silur und Unterdevon vom Thüringischen Typ in Sardinien und seine regionalgeologische Bedeutung. Nova Acta Leopoldina, Neue Folge, 224. pp. 263299.

Jaeger, H., Križ, J. \& Schönlaub, H. P. 1981: The Pridoli Series as the fourth Series of the Silurian System. A Submission to the Subcommission on Silurian Stratigraphy. pp. 1-41.

Jenkins, C. J. 1982: Late Pridolian Graptolites from Elmside Formation near Yass, New South Wales. Proce. Linn. Soc. N.S.W. 106.

Koren, T. N. 1983: New Late Silurian Monograptids from Kazakhstan. Palaeontology 26. pp. 407-434.

Križ, J., Jaeger, H., Paris, F., Schönlaub, H. P., Angelidis, A., Chlupač, I., Havliček, V., Kruta, M., Kukal, Z., Marek, J., Prokop, R., Snajdr, M. \& Turek, V. 1983: The Pridoli Series as the fourth Series of the Silurian System. A supplementary Submission to the Subcommission on Silurian Stratigraphy. pp. 1-59.
Lenz, A. C. 1966: Upper Silurian and Lower Devonian Palaeontology and Correlations, Royal Creek, Yukon Territory: A preliminary report. Bull. Can. Petr. Geol. 14. pp. 604-612.

Lenz, A. C. \& Jackson, D. E. 1964: New Occurrences of graptolites from the South Nahami Region, Northwest Territories and Yukon. Bull. Can. Petr. Geol. 12. pp. 892-900.

Lenz, A. C. \& Jackson, D. E. 1971: Latest Silurian (Pridolian) and Early Devonian of North-Western Canada. In: Contribution to Canadian Palaeontology. Geological Survey of Canada, Bull. 192. pp. 1-25.

Mikhajlova, N. F. 1971: Graptolitove zony silurijskikh otlozhenij Kazakhstana. Stratigraficzeskije Sovieszczanije po dopaleozoju i paleozoju Kazakhstana. Alma Ata. pp. 115117.

Mikhajlova, N. F. 1975: Graptolity. In: Kharakteristika fauny pogranitsnykh sloev silura i devona Tsentralnogo Kazakhstana. Materialy po geologii Tsentralnogo Kazakhstana 12. pp. 151-158.

Mikhajlova, N. F. 1976: Postludlovian graptolites of Kazakhstan (Summary). In: Graptolites and Stratigraphy. Tallinn. pp. 99-101.

Obut, A. M., Abduazimova, Z. M., Golikov, A. N. \& Rinenberg, R. E. 1968: Zonalnoe rasclenenie i korrelacija silurijskich otlojenij po graptolitam w Srednej Asii. In: Biostratigrafija pogranitsnykh otlojenij silura $i$ devona. AN SSSR Moskva. pp. 75-85.

Paškevicius, J. 1979: Biostratigraphy and Graptolites of the Lithuanian Silurian. Mosklas, Vilnius. pp. 1-230.

Přibyl, A. 1940: Graptolitova fauna ceskeho stredniho ludlovu. Vestnik Statniho geologiceskeho Ustavu. 16. pp. 63-73.

Pribyl, A. 1981: New graptolites of the Family Monograptidae from the Upper Silurian of Bohemia. Vestnik Ustredniho ustavu geologickeho, 56. pp. 371-375.

Pribyl, A. 1983: Graptolites biozones of the Kopanina and Pridoli Formations in the Upper Silurian of Central Bohemia. Casopis pro mineralogii a geologii, 28. pp. 149-167.

Thorsteinsson, R. 1958: Cornwallis and Little Cornwallis Islands, District of Franklin, Northwest Territories. Geological Survey of Canada, Memoir 294. pp. 1-134.

Teller, L. 1964: Graptolite fauna and stratigraphy of the Ludlovian deposits of the Chelm borehole, Eastern Poland. Studia Geologica Polonica, 13. pp. 1-88.

Teller, L. 1966: Two new species of Monograptidae from the Upper Ludlovian of Poland. Bull. Acad. Pol. Sci. II. 14. pp. 553-558.

Teller, L. 1969: The Silurian biostratigraphy of Poland based on graptolites. Acta Geologica Polonica. V., 19. pp. 393-501.

Tomczyk, H. \& Teller, L. 1956: The Ludlow deposits in Eastern Poland. Bull. Acad. Pol. Sci. III, 4. pp. 549-553.

Tsegelnjuk, P. D. 1976: Poznesilurijske i rannedevonske monograptidy jugo-zapadnoj okrainy vostocno-evropejskej platformy. Naukova Dumka, Kiev. pp. 91-133.

Urbanek, A. 1970: Neocucullograptinae n. subfam. (Graptolithina) their evolutionary and stratigraphic bearing. Acta Palaeontologica Polonica, 15. pp. 163-388.

Urbanek, A. 1971: Zonal evolution of monograptids in Siedlce beds, a new chapter in graptolite history. In: Granica Silura $i$ Devona i biostratigrafija Silura. 1, Leningrad. pp. 222-228.

Walliser, O. H. 1964: Conodonten des Silurs. Abhandlungen des Hessischen Landesamtes für Bodenforschung. 41. pp. 1-106.

Willefert, S. 1962: Quelques graptolites du silurien superieur du Sahara Septentrional. In: Bull. de la Societe geol. de France, serie, V. IV., 7. pp. 24-40. 